\title{
Characteristics of Ultisols under Different Wildfire History in South Sumatra, Indonesia: I. Physico-chemical Properties
}

\author{
Sabaruddin KADIR, Satoshi ISHIZUKA United Graduate School of Agricultural Science, Ehime \\ University, Matsuyama 790-8566, Japan \\ Katsutoshi SAKURAI, Sota TANAKA, Shinobu KUbOTA, Madoka HiRota Faculty of Agriculture, \\ Kochi University, Nankoku 783-8502, Japan \\ Satria Jaya PriAtNA, JUAIRIAH Faculty of Agricultue, Sriwijaya University, Palembang, South \\ Sumatra 30662, Indonesia
}

\begin{abstract}
Fire has become a great threat to Indonesian rainforest. However, informative data quantifying the effects of wildfire on the soils are still limited. We have been studying the leftover effect of forest fire on characteristics of Indonesian Ultisols. Current experiment evaluated physico-chemical characteristics of soils under different ecosystems with different wildfire history. Seven sites, which could be grouped into unburnt sites (conservation forest (CF), Pine forest (PF), Acacia mangium plantation (AM), and home garden (HG)) and burnt sites (Acacia mangium plantations burnt in 1995, 1997, and 1998) referred as AM-b95, AM-b97, and AM-b98, respectively, were sampled. Organic layer was found in $\mathrm{CF}, \mathrm{PF}$, and $\mathrm{AM}$ but not in any other sites. Morphologically, soils of unburnt sites had darker A horizon than those of burnt sites. In spite of lack of significant differences, bulk density decreased with increasing period after fire, indicating the recovery process. Although the upper layer of the burnt soils was physically harder than that of the unburnt soils, soil hardness did not appear to be a limiting factor for plant growth. Soil in the unburnt sites was chemically more acid but contained more organic $\mathrm{C}$ and $\mathrm{N}$ than that in the burnt sites. Surface soil of PF, AM-b98, and HG had much higher exchangeable $\mathrm{Ca}$ than any other sites. However the CEC was low across the study sites, irrespective of the high clay content. Available $\mathrm{P}$ was also low, and correlated with high $\mathrm{Al}$ solubility. Crystalline $\mathrm{Al}$, $\mathrm{Si}$, and $\mathrm{Fe}$ contents of all soils were higher than amorphous $\mathrm{Al}, \mathrm{Si}$, and $\mathrm{Fe}$ oxides. $\mathrm{ZPC}$ values were low across the study sites. However, higher negative charge generated by organic matter had resulted in lower ZPC values at the surface layer as compared with the subsurface layer. Although soils in the unburnt sites showed a better physico-chemical potential than the burnt sites, in general Ultisols in the study sites had undergone strong weathering and showed low natural fertility potential.
\end{abstract}

Key words: wildfire / tropics / Ultisols / physico-chemical / pine / Acacia mangium

In the last two decades, fire has become one of the greatest threats to Indonesian tropical rainforest. Boosted by the 1997/1998 El Nino phenomenon, uncontrolled fires have destroyed hundred thousands hectares of forests, plantations, agricultural fields, and bushes in Indonesia. Official estimates registered a figure of 263, 992 ha of various land-uses being scorched in Indonesia in 1997 alone. However, the coverage in the field might be much worse than the estimates. A recent study by Goenner (1998) reported a figure ranging from 8 to 10 million ha in East Kalimantan alone being destroyed by fire from mid 1997 to May 1998. A study by FFPCP (1997) reported a figure of 142,000 ha of land in South Sumatra destroyed by wildfires from 1993 to 1995 . Bompard and Guizol 
(1999) reported an estimate of 786,000 ha of forest including those on peat, smallhorder rubber plantation, pulpwood, timber plantation, and bushes in South Sumatra destroyed by fire in 1997 alone.

Apart from economic losses, the ecological damage was considerable. When biomass on or above soil surface burns, a heat pulse penetrates the soil. The resulting high temperatures can alter soil properties, and kill roots, seeds and soil microbes. Quantitative data on the impacts of wildfire in the tropics on soil quality are still limited, although some information is available for other vegetation types and different regions (Campbell et al., 1995; Dunn et al., 1979; Giovannini and Lucchesi, 1997; Kang and Sajjapongse, 1980; Marion et al., 1991). Each of those studies was limited to either sudden impacts of artificial heating or impacts of prescribed burning on soil properties. On the other hand data available quantifying long-term effects of wildfire on tropical soil characteristics are still limited, hence still poorly understood.

Understanding both sudden and delayed changes in soil properties associated with fires is crucial because soil fertility may decrease and subsequent site degradation may occur if inadequate management practices are employed after fires. Previous studies indicated that the soils over which fire has passed have been intensely eroded and profoundly degraded (Giovannini and Lucchesi, 1987), which is most likely due to reduced organic matter content, polysaccharides, and water stable aggregates (Domear et al., 1979), all factors associated with soil erodibility. Therefore it is important to follow eventual successive effects of the fire on the soil ecosystem. Since 1998, we have been monitoring the natural recovery of soil of different ecosystem with varied wild fire history in South Sumatra, Indonesia. This paper reports data on soil characteristics of different ecosystem with different wildfire history as baseline information for further characterization of dynamics of soil properties.

\section{MATERIALS AND METHODS}

\section{Study Site}

The study area was located in Pendopo Sub-district, Muara Enim District, South Sumatra Province, about $200 \mathrm{~km}$ Southwest to Palembang, Indonesia, stretching from $103^{\circ} 30^{\prime} \mathrm{E}$ to $103^{\circ} 50^{\prime} \mathrm{E}$ and $3^{\circ} 15^{\prime}$ $\mathrm{N}$ to $3^{\circ} 25^{\prime} \mathrm{N}$ (Fig. 1). Pendopo belongs to Type A zone with ratio of dry month to wet month $<1.5$ (Schmidt and Ferguson, 1951). Although there has been a seasonal shift, rainy season usually starts in September and ends in March with average annual precipitation of 2600 to $4200 \mathrm{~mm}$; dry season is from April to August. Air temperature is relatively similar all year long with mean annual temperature of $25^{\circ} \mathrm{C}$.

The study sites were located at elevation of approximately 60 to $140 \mathrm{~m}$ above sea level with slope ranging from 3\% to 16\%. Based on Geological Map (Gafoer et al., 1986), it was shown that soils in Pendopo Area developed from tertiary fine sedimentary rocks. Hapludults, Hapludox and Dystropepts could be found in the study area. The soils were Yellowish-brown Podzolic, and association between Yellowish-red Podzolic and Yellowish-brown Podzolic (LPT, 1974), equivalent to Acrisols (FAO/UNESCO, 1974) or Ultisols (Soil Survey Staff, 1992).

Seven sites ranging from conservation forest (CF) to 20-year old pine plantation forest (PF), unburnt 7-year-old Acacia mangium plantation (AM), and burnt Acacia mangium plantation in 1995(AM-b95), 1997 (AM-b97) and 1998 (AM-b98), were selected for this study. Starting from May 


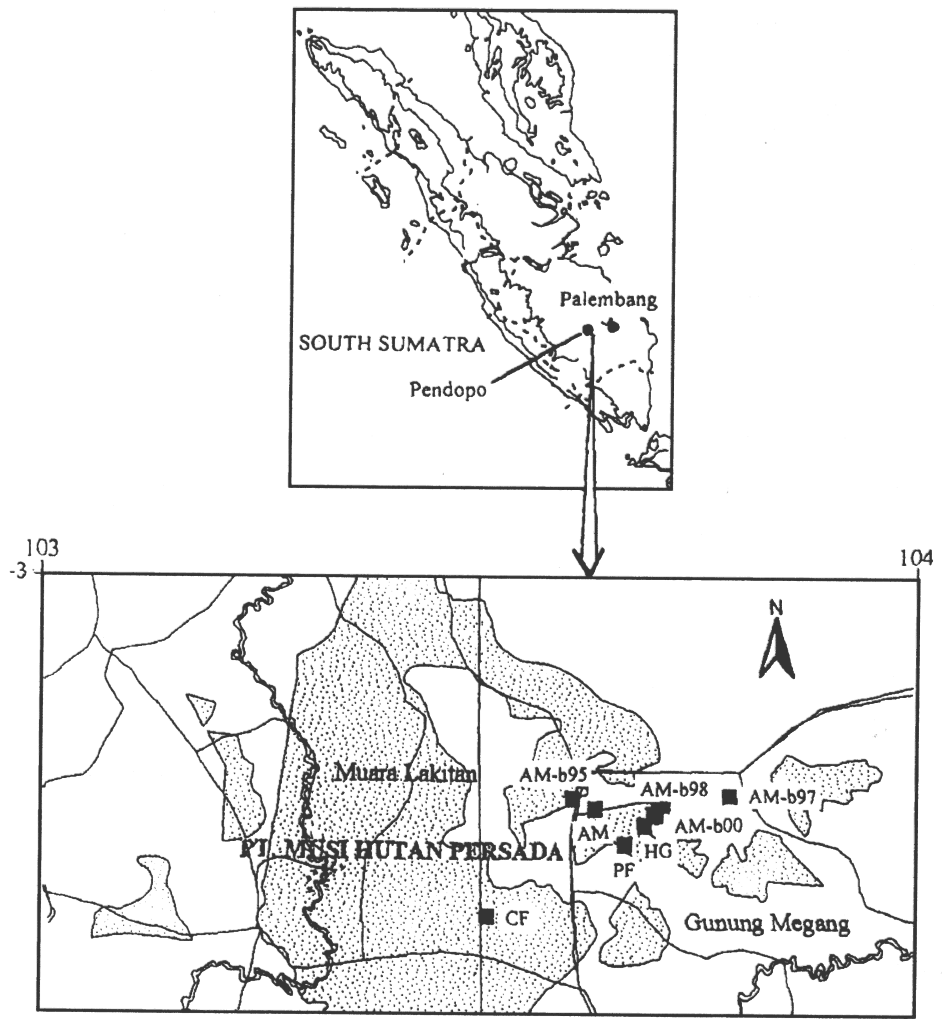

Fig. 1. Location of the study site in Pendopo, Muara Enim, South Sumatra Province, Indonesia.

1999, a home garden area (HG) was also included. In each selected site, a representative sub-plot of $50 \mathrm{~m} \times 50 \mathrm{~m}$ was established for soil sampling purposes.

The overstory of CF was mixed-tree species. Some primary species included Agathis loranthifolia Salibs, Peronema canescens Jack, Shorea spp., Altingia excelsa Noronhae, and Durio zibethinus Meur. Although this area has been designated as a conservation forest, it was not free from disturbances because people living in the vicinity have been using it as a source of living. In addition, illegal logging has also been taking place, resulting in open spots. As a result shrubs and grasses could be found as understory species. Pine (Pinus merkusii) forest was about 20 years old at the start of this experiment (December 1998). In the $50-\mathrm{m} \times 50 \mathrm{~m}$-plot, there were 56 stands of Pinus merkusii, with average gerth at breast height $(\mathrm{GBH})$ of $88 \mathrm{~cm}(54-143 \mathrm{~cm})$. The dominant understory species was ferns. The Acacia mangium plantation was either burnt or unburnt. The unburnt Acacia mangium was about 7 years old at the start of this study. There were 300 stands of Acacia mangium in the $50 \mathrm{~m} \times 50 \mathrm{~m}$-plot, with average GBH (based on 60 samples) of $44 \mathrm{~cm}$ (21 to $116 \mathrm{~cm})$. The understory species included Astonia sp., Caesalpinia pulchriina, Zingiber aromaticum vail. The burnt Acacia mangium had different burning history, namely in 1995, 1997, and 1998, respectively. Prewildfire vegetation was 5-year old, 6-year old, and <1-year old-Acacia mangium, consecutively. The burnt area had sparse regrowing Acacia mangium mixing with shrubs and grasses, mainly Imperata 
cylindrica as understory species. The home garden has been cultivated for two years at the start of this study. It was prepared by slashing the vegetation, piling, and burning. Long-term tree species was rubber tree (Hevea brasiliensis) with cassava (Manihot esculenta), banana, and some horticulture crops in the alley.

\section{Soil Sample and Analytical Methods}

Soil profiles were described in terms of color, texture, structure, consistency, and roots (Table 1). From each site, both undisturbed and disturbed soil samples were collected. The undisturbed soil cores were collected using $100 \mathrm{cc}$-soil corers from the depth of $0-10 \mathrm{~cm}$ for bulk density or hydraulic conductivity measurement. Bulk density was calculated based on the $100 \mathrm{cc}$-core and constant dry weight of the core following drying at $105^{\circ} \mathrm{C}$ for 24 hours. Moisture content was gravimetrically calculated after drying. Saturated water permeability was measured using a permeameter (Daiki, DIK 4000). Soil hardness was measured in the field using a fall-cone-type soil penetrometer (Daito Green Ltd. Hasegawa type H-60) to the depth of $60 \mathrm{~cm}$.

For physico-chemical characterization, soil samples were collected from each layer of pedons. Soil $\mathrm{pH}$ was measured in a soil to water or $1 \mathrm{M} \mathrm{KCl}$ ratio of $5 \mathrm{~g}$ to $25 \mathrm{~mL}$ (designated as $\mathrm{pH}-\mathrm{H}_{2} \mathrm{O}$ and $\mathrm{pH}-\mathrm{KCl}$, respectively). Electrical conductivity (EC) was measured after $\mathrm{pH}-\mathrm{H}_{2} \mathrm{O}$ measurement. The filtrate from $\mathrm{pH}-\mathrm{KCl}$ measurement was used for exchangeable $\mathrm{Al}$ and $\mathrm{H}$ analysis using the titration method. Exchangeable cations ( $\mathrm{Ca}, \mathrm{Mg}, \mathrm{K}$, and $\mathrm{Na}$ ) were extracted with $1 \mathrm{M} \mathrm{NH}_{4}-\mathrm{OAc}(\mathrm{pH} 7.0$ ), followed by reciprocal shaking and centrifugation in a soil to solution ratio of 5 to 25 , then measured by atomic absorption spectrophotometry (Shimadzu, AA-610S). Then, the pellet was washed with deionized water once and twice with $99 \% \mathrm{EtOH}$ to remove the salt excess. The ammonium was extracted with $10 \%-\mathrm{NaCl}$ solution twice, followed by reciprocal shaking for $1 \mathrm{~h}$ and centrifugation for $10 \mathrm{~min}$ at $1000 \mathrm{rpm}$. The ammonium ion content was determined as cation exchange capacity (CEC) by Kjedahl distillation and titration method. Total Carbon (T-C) and Nitrogen (T-N) were determined by a dry combustion method with NC-Analyzer (Sumigraph NC-80). The P-Bray-1 procedure was used to extract available $\mathrm{P}$, and the extract was colorimetrically analyzed for available $\mathrm{P}$ using a spectrophotometer at $660 \mathrm{~nm}$. $\mathrm{Al}, \mathrm{Fe}$, and $\mathrm{Si}$ oxides were extracted with $0.2 \mathrm{M}$ ammonium oxalate solution ( $\mathrm{pH} 3.0$ ), using reciprocal shaking in the dark for $1 \mathrm{~h}$ in a soil to solution ratio of 1 to 25 (Mckeague and Day, 1966), then designated as Alo, Feo, and Sio. Al, Fe, and Si oxides were also extracted with citrate-bicarbonate mixed solution $\mathrm{pH} 7.3$ with the addition of sodium dithionate at 75 to $80^{\circ} \mathrm{C}$ for $15 \mathrm{~min}$ in a soil to solution ratio of 1 to 100 (Mehra and Jackson, 1960), then designated as Ald, Fed, and $\mathrm{Si}$. Al, Fe, and $\mathrm{Si}$ were determined using a sequential plasma spectrometer (Shimadzu, ICPS-1000IV). Zero point of charge (ZPC) and $\sigma_{p}$ value were determined with STPT method (Sakurai et al., 1988).

\section{RESUT AND DISCUSSION}

\section{Soil Morphological Characteristics}

All sites were located in one compound area, except CF, which was about $20 \mathrm{~km}$ apart from the closest site (PF). Therefore, there might not be definitive differences in climate and geological time for long-term weathering. Topographically, all pedons were located in the middle slope of hills, with 
Table 1. Morphological characteristics of the soil

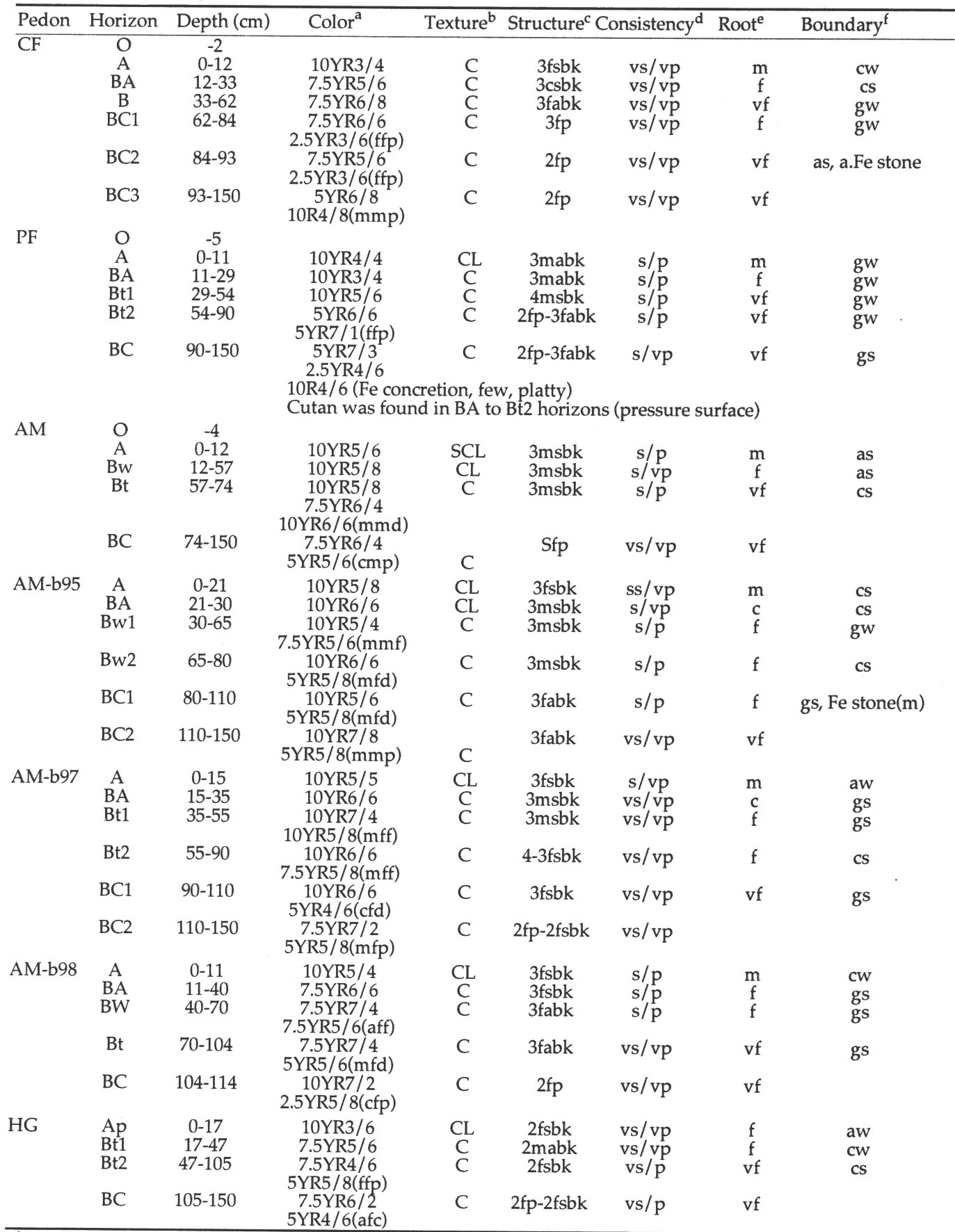

a) Lower row of each horizon indicates mottle color, followed by abundance, size, and contrast in the parenthesis. Abundance: $f$, few; $m$, many. Size: $f$, fine; $m$, medium. Contrast: $f$, faint; $d$, distinct; $p$, prominent. b) Abbreviation used for soil texture: $\mathrm{C}$, clay, $\mathrm{CL}$, clay loam.

A A sbk, sub-angular blocky; abk, angular blocky; p prismatic.

d) Abbreviation used for consistency. Stickiness: ss, slightly sticky; s, sticky; vs, very sticky. Plasticity: p, plastic; vp, very plastic.

e) Abbreviation used for root abundance. vf, very few; f, few; $m$, many

Abbreviation used for boundary. as, abrupt smooth; aw, abrupt wavy; cs, clear smooth; cw, clear wavy; gs, gradual smooth; gw, gradual wavy. 
slopes ranging from 6 degrees (CF, AM, AM-b95, AM-b97 and HG) to 8 degrees (PF and AM-b98), respectively. The morphological characteristics of soils are given in Table 1 . The study site had soils with deep solumn. Up to the depth of $150 \mathrm{~cm}$, neither rock fragment nor parent material was found. Organic layer was $5 \mathrm{~cm}$ in $\mathrm{PF}, 4 \mathrm{~cm}$ in $\mathrm{AM}$, and $2 \mathrm{~cm}$ in $\mathrm{CF}$, and composed of plant debris of varied floor growth in CF, Pine leaves and fern debris in PF, and Acacia mangium leaves in AM.

Darker A horizons were found in all pedons (Table 1). Organic matter (as will be shown in the following section) appeared to contribute significantly to the darker A horizon. Disturbances, such as land conversion and/or fire, to some extent affected soil color. Burnt areas (AM-b95, AM-b97, and AM-b98) showed lighter A horizon than unburnt areas. These changes were due to loss of organic matter caused by combustion and/or subsequent erosion. Exceptionally dark brown Ap horizon in HG site was related to regular plant debris turnover after harvest. Such condition could be maintained because slash- and-burn practice had never been applied to this home garden since it was established in 1997. Lighter colors dominated lower horizons throughout the study sites. Reddish mottling (2.5YR to 7.5YR) could be found at lower horizon in all pedons. Iron concretion was found in $\mathrm{CF}$, PF, and AM-b. 97 at $62 \mathrm{~cm}, 90 \mathrm{~cm}$, and $90 \mathrm{~cm}$, respectively.

Clay loam was a dominant texture class of surface soil except those of CF and AM which had clay and sandy clay loam, respectively (Table 1). At lower horizons, clay texture was found in all pedons. Also, blocky structures either moderately developed or strongly developed angular blocky and subangular blocky were found across the study sites. However weakly developed prismatic structure was also found in lower horizons of CF, PF, AM, AM-b97, and AM-b98, respectively. In accordance with soil texture, soil consistency ranged from sticky to very sticky and plastic to very plastic except in surface soil of AM-b95, which was slightly sticky (Table 1). The slightly sticky consistency could be attributed to clay loam texture of this layer (Table 1) due to high content of sand as confirmed by the result of soil particle analysis (Table 2). With depth, both the stickiness and plasticity increased mainly due to the increasing clay content. Fine roots concentrated in A horizon and decreased with depth.

\section{Soil Physical Properties}

\section{Soil Bulk Density}

Soil bulk density varied according to land-use system and fire history (Table 2). In the unburnt sites, the lowest bulk density $\left(0.99 \mathrm{~g} \mathrm{~cm}^{-3}\right)$ was observed in the CF soil, followed by PF soil $\left(1.10 \mathrm{~g} \mathrm{~cm}^{-3}\right)$ and AM soil $\left(1.15 \mathrm{~g} \mathrm{~cm}^{-3}\right)$. In the burnt sites the bulk densities were in the order of $1.01 \mathrm{~g} \mathrm{~cm}^{-3}, 1.10 \mathrm{~g}$ $\mathrm{cm}^{-3}$, and $1.13 \mathrm{~g} \mathrm{~cm}^{-3}$ for AM-b95, AM-b97, and AM-b98, respectively.

When the natural forest was cleared for certain purposes or underwent disturbances, such as fire, soil bulk density also increased. These increases were due to soil-structure deterioration during the operation of heavy machinery for land clearing and logging. Similar results on Nigerian and Australian soils had also been reported by Ghuman et al. (1991) and Huang et al. (1996), respectively. A study by Matarangan and Kobayashi (1999) showed that increases in soil bulk density of Indonesian soil (Riau and East Kalimantan) was to some extent affected by the frequency of tractor traffics. A significant increase was observed after the first and the second passage, followed by a slight increase after the third to the fifth passage.

Current study did not detect significant difference in soil bulk density among sites. However, in 
Table 2. Physical characteristics of soils in the study sites

\begin{tabular}{lcccccc}
\hline Site & $\begin{array}{c}\text { Bulk } \\
\text { density } \\
\left(\mathrm{g} \mathrm{cm}^{-3}\right)\end{array}$ & $\begin{array}{c}\text { Moisture } \\
\text { content } \\
(\%)\end{array}$ & $\begin{array}{c}\text { Saturated water } \\
\text { permeability } \\
\left(\mathrm{cm} \mathrm{s}^{-1}\right)\end{array}$ & \multicolumn{2}{c}{ Three-phase distribution } \\
Air & $\begin{array}{c}\text { Liquid } \\
(\%)\end{array}$ & Solid \\
\hline CF & 0.99 & 41.86 & $9.38 \times 10^{-04}$ & 33.5 & 44.23 & 22.27 \\
PF & 1.10 & 36.87 & $2.65 \times 10^{-04}$ & 6.60 & 66.55 & 26.85 \\
AM & 1.15 & 26.70 & $8.16 \times 10^{-05}$ & 9.63 & 55.71 & 34.66 \\
AM-b95 & 1.01 & 32.28 & $2.93 \times 10^{-04}$ & 4.25 & 58.76 & 36.99 \\
AM-b97 & 1.10 & 32.48 & $9.61 \times 10^{-05}$ & 2.90 & 49.88 & 47.22 \\
AM-b98 & 1.13 & 24.63 & $1.87 \times 10^{-07}$ & 0.00 & 43.34 & 56.66 \\
HG & NA & NA & $1.85 \times 10^{-06}$ & 8.15 & 60.88 & 40.97 \\
\hline
\end{tabular}

NA, not available

unburnt sites (CF, PF and AM), the length of vegetation (tree species) coverage appeared to be influential. This was shown by decreasing bulk density of PF and AM soils, approaching the value of forested soil. The turnover of organic matter in these sites seemed to be an important contributing factor. As shown previously, an accumulation of plant debris could be found both on the surface of PF and AM sites (Table 1). The importance of organic matter turnover into degraded soils in soil bulk density recovery had been demonstrated both in young temperate-zone soils and in the old, highly weathered soils of the tropics (Nye and Greenland, 1964; Sanchez et al., 1985). A recent study by Fisher (1995) reported a decrease of bulk density of degraded rain forest soils of Costa Rica from 0.64 to $0.54 \mathrm{~g} \mathrm{~cm}^{-3}$ following an increase of soil organic carbon from 0.73 to $0.77 \mathrm{~g} \mathrm{~kg}^{-1}$ after three years Acacia mangium plantation.

Soil bulk density of CF reported in the current study $\left(0.99 \mathrm{~g} \mathrm{~cm}^{-3}\right)$ was somewhat higher than those reported earlier (e.g. Fisher, 1995; Huang et al., 1996). Heavy texture (reflected by high clay content) seemed to be the main cause of higher BD in the current study than those appeared in the literatures. In addition, the anthropogenic disturbances, such as the exploration for rattan, resin of Shorea sp. and fire woods, and illegal logging, might also have contributed. With time such activities increased as the populations increased, causing more pressure to the forest. However, the values were still lower than those of other sites mainly because those activities were carried out manually whereas in other sites (PF and AM) it was carried out mechanically.

In burnt sites, soil bulk density also varied according to the length of post-fire period (Table 2). The highest bulk density $\left(1.13 \mathrm{~g} \mathrm{~cm}^{-3}\right)$ was detected in AM-b98. This increase was resulted by decreasing organic volume of the soil due to combustion; whereas the contribution of materials with higher density (mineral) increased. In current experiment, increasing solid phase was also detected as the natural ecosystem (CF) was converted into plantation (PF and AM) or agricultural land (HG) (Table 2). The effect was even stronger when the sites burnt, as in the AM-b95, AM-b97, and AMb98 soil (Table 2). However, with time, the value decreased to $1.10 \mathrm{~g} \mathrm{~cm}^{-3}$ in AM-b97 and $1.01 \mathrm{~g} \mathrm{~cm}^{-3}$ in AM-b95, and approaching the value of CF soil (Table 2). Interestingly, time required for recovery appeared to be shorter compared with the unburnt sites. When plant biomass (fuel) on soil surface burns a heat pulse penetrated the soil to certain depth. Increases in soil temperature above normal, beyond the tolerable degree, killed below-ground biomass including roots. Wild fires occurring in the study sites had killed most if not all vegetations. Then the dead roots became a good source of organic matter turnover into the soil. Because of the effect of soil heating, the dead roots decomposed 
easily, contributing to the earlier replenishment of soil fertility.

Moisture contents were markedly different among the study sites (Table 2). In the unburnt sites, the highest moisture content (42\%) was recorded in CF soil, followed by PF soil (37\%), AM soil (27\%), respectively. Naturally, forest soils especially under mature natural forest, in comparison with cultivated soils, generally had high infiltration, as shown by faster water permeability in Table 2 $\left(9.38 \times 10^{-14} \mathrm{~cm} \mathrm{~s}^{-1}\right)$, and relatively low run-off and erosion potential. The water holding capacity was also ensured due to high organic matter content (as will be shown in the subsequent section). In contrast, the evaporation rate was low due to dense canopy closure. As disturbance, for example land clearing and wild fires as the case in current study, occurred, compaction that might adversely affect soil structure and caused changes to soil hydraulic conductivity would result in changes in water distribution. This case might have occurred in PF and AM soils. After land clearing usually the area was not directly planted. When the rain came, the soils easily got saturated and erosion started to occur, exposing subsoil to the surface. The interventions of wildfire caused further degradation of soil quality. Therefore, in current study the moisture contents of soils in the planted forest (PF and AM) were lower than that of CF soil. In addition, the vertical movement of water in the soil profile, as shown by water permeability was also decreased (Table 2).

In the burnt sites, the lowest moisture content (25\%) was observed in AM-b98 soil; there was no difference between AM-b97 and AM-b95 soils which had water content of $32 \%$ (Table 2). Mechanisms described earlier might have significant contribution to moisture status of these two sites. In addition, open space resulted from wildfire supported the chances of high evaporation to occur.

These results confirmed the importance of soil coverage in conserving water in soil because it could reduce evaporation. In addition, accumulation of plant debris on the surface also had significant contribution.

\section{Soil Hardness}

Soil hardness measurement using a cone-type penetrometer provides valuable information to predict physical hazard for plant growth without causing significant disturbance to the plant stands (Hasegawa et al., 1984; Sakurai et al., 1995). In this study, soil hardness was measured along the transect (upper, middle, and lower slopes) and within different times (September 1999/dry season, December 1999/rainy season and March 2000/beginning of dry season) to study the spatial and seasonal variability of soil hardness. However, in CF data for December 1999 were not available because we could not approach this site due to muddy road. Each point of observation was about 15 m apart. Representative vertical distributions of soil hardness in the study area are given in Fig. 2 .

Although the penetrometer could very well penetrate the $60-\mathrm{cm}$ depth, indicating the absence of gravel or rock layer, the total count at each site and each point was varied. The absence of gravel layer was also confirmed by the observation made on the soil profile (Table 1). The highest count of penetrometer (125 counts) was observed in lower slope of AM Area; whereas the lowest (36 counts) was observed in middle slope of AM-B97. The total count in other sites ranged between those two figures.

At the first $10-\mathrm{cm}$ depth, soil hardness showed a similar pattern across space and season. However, burnt areas had higher counts in the first $10-\mathrm{cm}$ layer than unburnt areas (Fig. 2). These results were in agreement with the results on the bulk density, which was higher in the burnt areas 

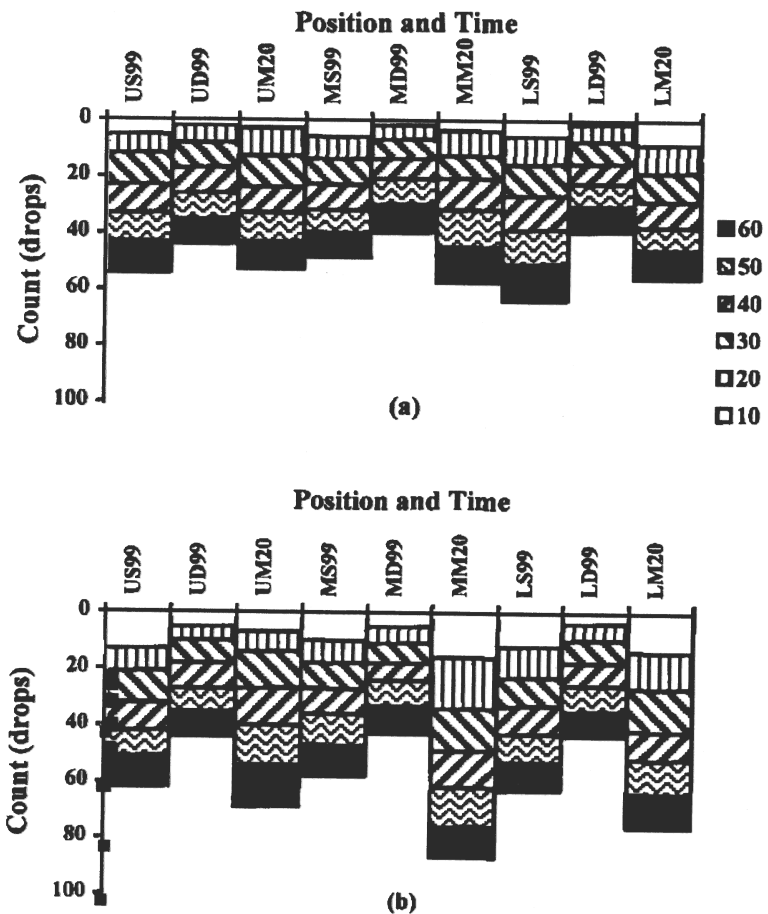

Position and Time

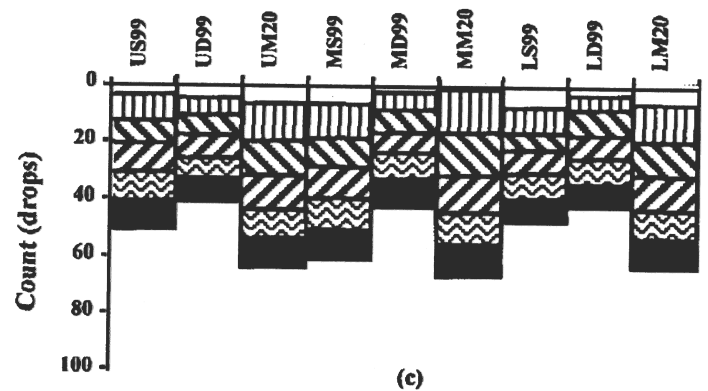

Fig. 2. Penetrometer count in PF (a), AM (b), and HG (c) areas at the upper slope (U), middle slope (M) and lower slope (L), in September (S), December (D), and March (M).

than in the unburnt areas (Table 2). The lower counts in HG compared with AM-b98 was due to regular soil tillage carried out in this area prior to crop planting.

Increasing depth tended to be followed by increasing total count of penetrometer across the study site. Because soil hardness could reflect the presence of clayey materials in lower layers of a pedon, the increasing soil hardness with depth might be attributed to increasing clay content with depth (Table 4). However, in current study there was no enough information to support this argument because soil penetrability was calculated with $10-\mathrm{cm}$ increment of soil depth, whereas clay content was measured in each soil horizon, which had different depth. Nevertheless, regression on three-point observation, for example in the AM Area, showed a significant correlation $\left(\mathrm{r}^{2}=0.99, P<0.001\right)$ of soil hardness and clay content.

Spatial variability of soil hardness seemed to be season dependent. During dry season (September 
Table 3. Chemical characteristic of soil from pedons

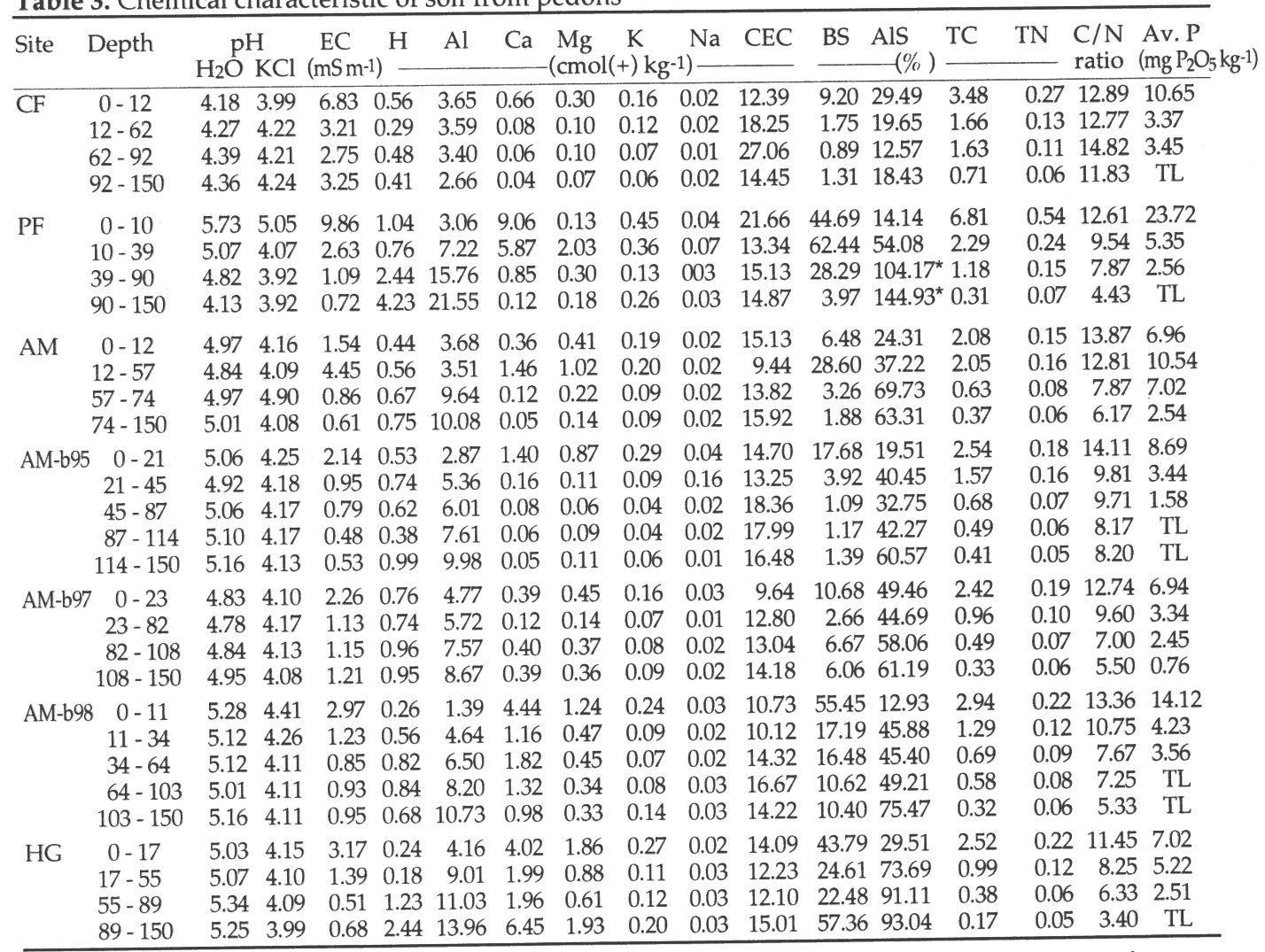

$\mathrm{CEC}$, cation exchange capacity; $\mathrm{BS}$, base saturation $((\mathrm{Ca}+\mathrm{Mg}+\mathrm{K}+\mathrm{Na}) / \mathrm{CEC} \times 100)$; AlS, Aluminum saturation $(\mathrm{Al} / \mathrm{CEC} \times 100)$; TC, total carbon; TN, total nitrogen; Av. P, available phosphorus; TL, too low. $\left.{ }^{*}\right)$ due to high exchangeable $\mathrm{Al}$.

1999), the highest count was obtained in lower part of all sites except CF and HG in which the lower slope showed the least count. In the rainy season, the total counts decreased markedly but did not show a great spatial variability (31 to 44), except in AM-b97 where a total count of 69 was recorded. By the end of rainy season (March 2000), the total counts increased but did not show similar pattern across the study site.

Based on these results, it can be concluded that soil hardness does not seem to be a limiting factor for plant growth. It was also confirmed by the presence of roots up to the depth of $150 \mathrm{~cm}$ (Table 1).

\section{Soil Chemical Properties}

The chemical properties of soils in the study sites are given in Table 3. Soil acidity ranged from very acid to slightly acid. Release and hydrolysis of $\mathrm{Al}$ under strong leaching condition produced acidity in these soils. At low $\mathrm{pH}, \mathrm{Al}$ is present in the exchange complex and diffuses into soil solution where it may lower the $\mathrm{pH}$ and cause toxicity. Higher $\mathrm{pH}$ mainly in the upper layer of $\mathrm{PF}$ soil $(\mathrm{pH}=5.73)$ was most likely due to much higher content of $\mathrm{Ca}$ in this soil than in any other soils (Table 3). However, only at CF Al saturation was slightly lower compared with other plantation forest and HG. This might be due to disturbances by human management. PF might be affected by the translocation 
of $\mathrm{Al}$ from the surface layer, dissolved by the organic matter accumulated on the surface. The deeper layer of HG might also be affected greatly by the agricultural practices, which enabled water percolation by the cultivation at the surface.

Soils in the burnt sites in general had higher $\mathrm{pH}$ than those in the unburnt sites. The ash from plant materials was high in basic cations such as calcium, potassium, and magnesium. Hence, the liming effect of these cations tended to raise the $\mathrm{pH}$. Somewhat higher $\mathrm{pH}$ in the HG soil was due to liming applied prior to crop planting. Unfortunately, no definitive rate of liming could be recorded. However, based on the results on the Al saturation (Table 3) which was still high, it could be assumed that the amount of liming material used was still below the recommended rate. Hence only was the active acidity neutralized.

In the unburnt site, total $\mathrm{C}$ and $\mathrm{N}$ contents, reflecting the comparative amount of organic matter, were markedly different among sites. Permanently covered sites (CF) and the sites free from fire disturbance (PF) had higher $\mathrm{C}$ and $\mathrm{N}$ contents than the other sites. The highest $\mathrm{C}$ content in the surface layer was found in PF soil (6.81\%); whereas the lowest was in AM soil (2.08\%). As shown previously, the PF site had the thickest organic layer $(5 \mathrm{~cm})$, comprising of decomposed, partly decomposed, and fresh Pine leaves and fern debris. On the other hand although the thickness of organic layer of AM soil $(4 \mathrm{~cm})$ was not different from that of PF soil, the C content was the lowest. Observation in the field showed that organic layer in AM soil mostly consisted of undecomposed Acacia mangium leaves.

In the burnt sites, the most recently burnt area (AM-b98) had the highest total $\mathrm{C}$ and $\mathrm{N}$ in the surface layer (Table 3). At $2 \mathrm{yr}$ after fire (AM-b97), however, both total $\mathrm{C}$ and $\mathrm{N}$ slightly decreased and increased again at $4 \mathrm{yr}$ (AM-b95), approaching the value of CF soil (Table 3). These results suggested that in term of total $\mathrm{C}$ and N, 4 yr after passage of the fire, the surface soils regained their original organic $\mathrm{C}$ and $\mathrm{N}$ levels. An extra input from the decomposing dead roots was probably responsible for their recovery.

Vertical distribution of $\mathrm{C}$ and $\mathrm{N}$ shared similar pattern across the sites. As the soil depth increased, both $\mathrm{C}$ and $\mathrm{N}$ contents decreased. In accordance with lateral and vertical variability of $\mathrm{C}$ and $\mathrm{N}$ contents, $\mathrm{C} / \mathrm{N}$ ratio also varied according to sites but shared similar vertical variability. Toward deeper layers, $\mathrm{C} / \mathrm{N}$ ratio dropped significantly $\left(\mathrm{r}^{2}=0.72^{* *}, P<0.001\right)$. This occurred because the higher consumption of $\mathrm{N}$ than $\mathrm{C}$ by microbes at the surface layer.

The amount of exchangeable bases, except $\mathrm{Na}$ was much higher in the surface layer than in the subsurface layer. In particular Ca in surface soil of PF, AM-b98 and HG was much higher than in any other sites (Table 3). Several mechanisms could be responsible for the high solubility of Ca in these three sites. In AM-b98, it is possible that it was due to wild fire occurring prior to sampling. Heating at low temperature up to $100^{\circ} \mathrm{C}$ had been reported to increase $\mathrm{NH}_{4}$-extractable $\mathrm{Ca}$, which then decreased at temperature $>200^{\circ} \mathrm{C}$ (Kang \& Sajjapongse, 1980; Kitur \& Frye, 1983). In addition, the input from the ash might also have contributed significantly. The high exchangeable Ca in HG soil was mainly due to liming to eliminate Al toxicity. The commonly used lime material was $\mathrm{CaMg}(\mathrm{CO})_{2}$. Therefore this material could also be expected as a source of both Ca and $\mathrm{Mg}$. However, the liming failed to minimize the solubility of $\mathrm{Al}$ in the soil of $\mathrm{HG}$, shown by high $\mathrm{Al}$ saturation (30\%) in this soil (Table 3). The failure was most probably related to insufficient liming materials used. In PF, a different mechanism might have taken place. Pine has been suggested as a 
Table 4. Charge characteristics and sesquioxide properties

\begin{tabular}{|c|c|c|c|c|c|c|c|c|c|c|c|c|c|c|}
\hline \multirow{2}{*}{\multicolumn{2}{|c|}{ Site Depth $(\mathrm{cm})$}} & \multirow[t]{2}{*}{ Alo } & \multirow[t]{2}{*}{ Feo } & \multirow{2}{*}{$\begin{array}{l}\text { Sio } \\
-\%\end{array}$} & \multirow[t]{2}{*}{ Ald } & \multirow[t]{2}{*}{ Fed } & \multirow{2}{*}{ Sid } & \multirow{2}{*}{ Alo/Ald } & \multirow{2}{*}{$\mathrm{Feo} / \mathrm{Fed}$} & \multirow{2}{*}{$\mathrm{ZPC}$} & \multirow{2}{*}{$\sigma_{\mathrm{p}}$} & \multicolumn{3}{|c|}{ Soil Fraction } \\
\hline & & & & & & & & & & & & & & \\
\hline & & 0.209 & 0.329 & 0.016 & 0.277 & 4.866 & 0.191 & 0.755 & 0.068 & 3.57 & 2.32 & 70.13 & 9.63 & 20.24 \\
\hline & & & & & & & & & & & & 74.10 & 8.90 & 17.00 \\
\hline & & & & & 1.015 & 6.166 & & 0.228 & 0.071 & 4.00 & 0.56 & 73.48 & 8.45 & 18.07 \\
\hline & & 0.16 & 0.089 & 0.020 & 0.968 & 6.801 & 0.056 & 0.174 & 0.013 & 4.36 & 0.33 & 72.10 & 10.15 & 17.75 \\
\hline \multirow[t]{4}{*}{ PF } & & 0.361 & 0.532 & 0.031 & 0.662 & 3.014 & 0.161 & 0.545 & 0.177 & 4.23 & 10.00 & 60.17 & 24.79 & 15.04 \\
\hline & & & & & & & & & & & & & & 16.22 \\
\hline & & & 0.2 & & $0.8 \varepsilon$ & 3.94 & & 0.429 & & & & 71.70 & 17.9 & 10.39 \\
\hline & & & 0.17 & 0.02 & 0.766 & 3.870 & 0.130 & 0.513 & 0.044 & 3.53 & 3.06 & 66.49 & 28.33 & 5.18 \\
\hline \multirow[t]{3}{*}{$\mathrm{AM}$} & 12 & 0.170 & 0.542 & 0.009 & 0.388 & 2.154 & 0.102 & 0.438 & 0.252 & 3.87 & 1.00 & 30.47 & 15.04 & 54.49 \\
\hline & & & & & & & & & & & & .54 & & 19.73 \\
\hline & & & & & & $\begin{array}{l}3.494 \\
5.157\end{array}$ & & & & & $\begin{array}{l}1.84 \\
1.46\end{array}$ & $\begin{array}{l}57.96 \\
62.89\end{array}$ & $\begin{array}{l}31.60 \\
27.18\end{array}$ & $\begin{array}{r}10.44 \\
9.93\end{array}$ \\
\hline \multicolumn{2}{|c|}{ AM-b95 } & 0.188 & 0.413 & 0.010 & 0.415 & 2.097 & 0.117 & 0.453 & 0.197 & & 2.67 & 31.30 & 15.16 & 53.54 \\
\hline & & & & & & & & & & & & .77 & & \\
\hline & 0 & 0.17 & & & 77 & 3.5 & & & & & & 40.31 & 14. & 44.75 \\
\hline & & 0.17 & 0.0 & & 0.5 & 3.6 & & & & & & 50.17 & & 34.37 \\
\hline & $114-150$ & 0.206 & 0.07 & 0.01 & 0.505 & 4.626 & 0.097 & 0.408 & 0.016 & 4.00 & 1.20 & 58.53 & 17.26 & 24.21 \\
\hline \multicolumn{2}{|c|}{ AM-b97 } & 0.203 & 0.455 & 0.012 & 0.519 & 2.663 & 0.119 & 0.391 & 0.171 & 3.71 & 1.70 & 45.33 & 29.36 & 25.31 \\
\hline & & & & & & & & & & & & & & \\
\hline & & & & & & & & & & & 1.78 & 57.75 & 24. & 18.1 \\
\hline & $108-150$ & & 0.084 & 0.012 & 0.584 & 4.431 & & 0.327 & 0.019 & 3.87 & 1.75 & 58.46 & & 16.73 \\
\hline \multicolumn{2}{|c|}{ AM-b98 $0-11$} & 0.209 & 0.469 & 0.015 & 0.379 & 1.786 & 0.097 & 0.551 & 0.263 & 4.54 & 2.33 & 38.38 & 33.31 & 2831 \\
\hline & & 0.205 & & & & & & & & & & 4.94 & 30.32 & \\
\hline & & & & 0.0 & & & & & & & & 52.42 & & \\
\hline & & 0.1 & 0.1 & & & & & & & & & 55.69 & & \\
\hline & & & & & 0.620 & 4.447 & 0.092 & 0.347 & 0.021 & 3.94 & 0.70 & 60.05 & & \\
\hline \multirow[t]{4}{*}{ HG } & & 0.254 & 0.386 & 0.021 & 0.587 & 2.811 & 0.139 & 0.433 & 0.137 & 3.27 & 8.19 & 44.19 & 22.26 & \\
\hline & & & & & & & & & & & & 51.29 & & \\
\hline & & & & & 0.677 & 3.9 & & 0.3 & & & 3.33 & 43.48 & & \\
\hline & $89-150$ & 0.286 & 0.089 & 0.022 & 0.655 & 3.109 & 0.123 & 0.437 & 0.029 & 3.75 & 3.22 & 60.82 & 23.66 & \\
\hline
\end{tabular}

species that acts as cation pump (Alban, 1982) that takes up high level of cations from deeper layer and accumulates those cations in the upper layer. The high availability of $\mathrm{Ca}$ in the surface layer of $\mathrm{PF}$ and AM-b98 caused the dominance of this cation on the exchange complex. This was reflected by the high base saturation in the surface soil of these two sites. On the hand the solubility of $\mathrm{Al}$ was restrained, shown by the low Al saturation (Table 3).

Cation exchange capacity (CEC) did not show a consistent pattern in all sites (Table 1). In general the soils in the study area had low CEC, irrespective of the high clay content. The CEC/Clay ratio of soil varied in the surface soil but not in the deeper layer. Because the soil across the study site had high clay content, the CEC/Clay ratio was also low except in AM soil (Table 3). It suggested that the main source of CEC was the clay. However, because the clay mineral was dominated by kaolinite, the CEC remained low.

Available P (P-Bray 1) was low across the study sites (Table 3). However, available P in the surface layer was consistently higher than in the subsurface layer. In the subsurface layer of some soils the available $\mathrm{P}$ was even too low to be detected. The low $\mathrm{P}$ availability was significantly correlated $\left(\mathrm{r}^{2}=0.53^{* *}, P=0.002\right)$ with high Al solubility in these soils. As solubility of Al was high, $\mathrm{P}$ formed Al-P complexes, which were not soluble. As generally acknowledged, the only source of $\mathrm{P}$ 
supply in nature is organic matter decomposition. In current study we also found a significant relationship $\left(\mathrm{r}^{2}=0.67^{* *}, P<0.001\right)$ between the available $\mathrm{P}$ and the total $\mathrm{C}$ content. Because the total $\mathrm{C}$ content decreased with increasing depth, the availability of $\mathrm{P}$ also declined with depth.

The results of oxide extraction are given in Table 4. Crystalline $\mathrm{Al}, \mathrm{Si}$, and $\mathrm{Fe}$ (Ald, Fed, and Sid) contents of all soils were higher than amorphous $\mathrm{Al}, \mathrm{Si}$, and $\mathrm{Fe}$ oxides (Alo, Feo, and $\mathrm{Sio}$ ). In particular, Fed contents in all soils were significantly higher than that of Feo. Higher values of Ald and Fed indicated the relative accumulation of oxidized $\mathrm{Al}$ and $\mathrm{Fe}$ associated with strong weathering. The activity ratio of $\mathrm{Al}$ (Alo/Ald) ranged from 0.174 to 0.755 , while that of $\mathrm{Fe}$ (Feo/Fed) ranged from 0.016 to 0.171 (Table 4). When compared throughout the study area, permanently covered sites (for example $\mathrm{CF}$ and $\mathrm{PF}$ ) showed higher value of Alo, resulting in higher Alo/Ald, than any other areas. These results were in agreement with those previously reported for Thai soils under para rubber plantation (Sakurai et al., 1996). They further argued that the continuous supply of organic matter might have prevented weathering and leaching of the amorphous forms of these elements. This argument was also in accordance with findings in current study which showed that both CF and PF had the highest $\mathrm{C}$ among soils examined (Table 3).

The results of ZPC determination are presented in Table 4. All soils across the study sites had very low ZPC values, mostly below 4.00. The soils under natural vegetation usually showed a lower ZPC value at the surface layer than the subsurface layer due to higher negative charge generated by organic matter at the surface (Sakurai et al., 1989). This was true for most of the soils in the current paper. However, PF and AM-b98 showed higher ZPC value at the surface layer than the subsurface layer. This phenomenon could be attributed to the higher amorphous oxides contents (Alo and Feo) and exchangeable $\mathrm{Ca}$ and $\mathrm{Mg}$ at the surface layer. These characteristics had been known to make ZPC value higher (Sakurai et al., 1989; Sakurai et al., 1996). The increase in Alo and Feo contents was brought by an accumulation of organic matter at the surface layer. Higher $\mathrm{Ca}$ and $\mathrm{Mg}$ content at the surface layer would be brought as the addition of the ash for AM-b98 (recently burnt site) and as an accumulation of undecomposed organic matter for PF. Excluding the surface layer of all sites, ZPC values of subsurface layers were in a narrow $\mathrm{pH}$ range across the study area, suggesting the weathering status of the soils would be similar. At the deepest layers in each profile, ZPC values were slightly higher than the overlying layers. This could be ascribed to the accumulation of oxides along with the accumulation of clayey materials, as indicated by Sakurai et al. (1989 and 1996).

The values of $\sigma_{p}$ ranged from very low to very high $(0.33$ to 10.00$)$. Only at the surface layers of PF and HG, this value exceeded 6.0. Toward lower horizon, the $\sigma_{p}$ decreased. Similar results had also been reported for Thai soils (Sakurai et al., 1989). Since the exchange site of permanent negative charge is mostly occupied by $\mathrm{Al}$ when $\mathrm{Al}$ content is high, the amounts of basic cations retained by the permanent negative charge are low. Therefore, base saturation is low but $\mathrm{Al}$ saturation is high in the tropical Ultisols. When evaluating the ZPC value by the STPT method (Sakurai et al., 1988), Al dissolution during determination of ZPC did not proceed greatly (Sakurai et al., 1990). Since $\sigma_{p}$ is defined as a remaining charge at $\mathrm{ZPC}$, the magnitude of $\sigma_{\mathrm{p}}$ was closely correlated with the amount of exchangeable bases. Thus the value of $\sigma_{p}$ can be an estimate of acting permanent negative charge in the field condition (Sakurai et al., 1988). Hirai et al. (1991) showed a significant correlation between $\sigma_{p}$ value and the sum of cations. In addition, the sum of cations $(\mathrm{Ca}+\mathrm{Mg}+\mathrm{K}+\mathrm{Na})$ at the surface layers often exceeded the magnitude of $\sigma_{p}$ value (Tables 3 and 4), suggesting that the cations were existing 
as free ions or loosely complexed with the organic matter.

ACKNOWLEDGEMENTS The authors thank Musi hutan Persada (MHP), Acacia mangium Agroforestry Company, South Sumatra, Indonesia for its support. The work reported here was also made possible by permit given by Institute of Land Rehabilitation and Conservation, and Department of Forestry, South Sumatra, Indonesia. The authors are grateful for the support of these organizations. Technical help by Mr. Agus Hermawan, Mr. Momon Sodik, and Mr.Dinupan during field-work is also highly acknowledged. The part of this study was financially supported by Japan Science Society (JSS) No. 12-260.

\section{REFERENCES}

Alban, D.H. 1982. Effects of nutrient accumulation by aspen, spruce and pine on soil properties. Soil Sci. Soc. Am. J. 46:853-861.

Bompard, J.M., and P. Guizol. 1999. Land management in the Province of South Sumatra, Indonesia. Fanning the flames: The institutional causes of vegetation fires. Forest Fire Prevention and Control Project and Ministry of Forestry and Estate Crops, Palembang, Indonesia.

Campbell, G.S., J.D. Jungbauer, K.L. Bristow, and R.D. Hungerfold. 1995. Soil temperature and water content beneath a surface fire. Soil Sci. 159:363-374.

Dunn, P.H., L.F. Debano, and G. E. Eberlein. 1979. Effects of burning on chaparral soils: II. Soil microbes and nitrogen mineralization. Soil Sci. Soc. Am. J. 43:509-514.

Domear, J.F., U.J. Pittman, and E.D. Spratt. 1979. Burning crop residues: Effect on selected soil characteristics and long-term wheat yields. Can. J. Soil Sci. 59:79-86.

FAO/UNESCO. 1974. Soil map of the world. Vol. 1. Unesco, Paris. 59 pp.

Fisher, R.F. 1995. Amelioration of degraded rain forest soils by plantation of native trees. Soil Sci. Soc. Am. J. 59:544-549.

Forest Fire Prevention and Control Project (FFPCP). 1997. Coal seam fires in South Sumatra. Forest Fire Prevention and Control Project, Dept. of Forestry, South Sumatra, Indonesia.

Gafoer, S., T. Cobrie, dan J. Purnomo. 1986. Peta geologi lembar Lahat, Sumatra Selatan,Skala 1: 250.000. Puslitbang Geologi Bandung.

Ghuman, B.S., R. Lal, and W. Shearer. 1991. Land clearing and use in the humid Nigerian tropics: I. Soil physical properties. Soil Sci. Soc. Am. J. 55:178-183.

Giovannini, G, and S. Lucchesi. 1987. The natural evolution of a burned soil: A three-year investigation. Soil Sci. 143:220-226.

1997. Modification induced in soil physico-chemical parameters by experimental fires at different intensities. Soil Sci. 162:478-486.

Goenner, C.C. 1998. Conflicts and fire causes in a Sub-district of Kutai, East Kalimantan, Indonesia. International Cross Sectoral Forum on Forest Fire Management in South Asia.

Hasegawa, S., M. Tabata, T. Kozawa, and Y. Sato. 1984. Relationship between physicality of soil and tree vigor in planting area made by heavy construction machine: An example of highway planting area. Jour. Japanese Institute Landscape Architects 48:104-122. (In Japanese with English summary). 
Hirai, H., K. Yoshikawa, K. Sakurai, and K. Kyuma. 1991. Characteristics of the soils Developed under broad-leaved evergreen forests in Okinawa Prefecture and the Kinki District with special reference to their pedogenetic processes. Soil Sci. Plant Nutr. 37:509-519.

Huang, J., S.T. Lacey, and P.J. Ryan. 1996. Impact of forest harvesting on the hydraulic properties of surface soil. Soil Sci. 161:79-86.

Kang, B.T., and A. Sajjapongse. 1980. Effect of heating on properties of some soils from southern Nigeria and growth of rice. Plant and Soil 55:85-95.

Kitur, B.K., and W.W. Frye. 1983. Effect of heating on soil chemical properties and growth and nutrient composition on corn and millet. Soil Sci. Soc. Am. J. 47:91-94.

Lembaga Pemetaan Tanah (LPT). 1974. Peta tanah tinjau Propinsi Sumatra Selatan. Lembaga Penelitian Tanah, Bogor, Indonesia.

Marion, G.M., J.M. Moreno, and W.C. Oechel. 1991. Fire severity, ash deposition, and clipping effects on soil nutrients in chaparral. Soil Sci. Soc. Am. J. 55:235-240.

Matarangan, J.R. and H. Kobayashi. 1999. The effect of tractor logging on forest soil compaction and growth of Shorea selanica seedlings in Indonesia. J. For. Res. 4:13-15.

Mckeague, J.A. and J.H. Day. 1966. Dithionite- and oxalate-extractable Fe and $\mathrm{Al}$ as aids in differentiating various classes of soils. Can. J. Soil Sci. 46:13-22.

Mehra, O.P. and M.L. Jackson. 1960. Iron oxide removal from soils and clays by a dithionite-citrate system buffered with sodium bicarbonate. Clay Miner. 7:317-327.

Nye, P.H. and D.J. Greenland. 1964. Changes in the soil after clearing tropical forest. Plant Soil 21:101-112.

Sakurai, K., B. Puriyakorn, P. Prechapanya, V. Tanpibal, K. Muangnil, and B. Prachaiyo. 1995. Improvement of biological productivity in degraded lands in Thailand: III. Soil hardness measurement in the field. Tropics 4(2/3):151-172.

Sakurai, K., Y. Ohdate, and K. Kyuma. 1988. Comparison of salt titration and potentiometric titration methods for the determination zero point of charge (ZPC). Soil Sci. Plant Nutr. 34(2):171-182.

- 1989. Factors affecting zero point of charge (ZPC) of variable charge soils. Soil Sci. Plant Nutr. 35(2):21-31.

Sakurai, K., A. Teshima, and K. Kyuma. 1990. Changes in zero point of charge (ZPC), specific surface area (SSA), and cation exchange capacity (CEC) of kaolinite and montmorillonite, and strongly weathered soils caused by Fe and Al coatings. Soil Sci. Plant Nutr. 36:73-82.

Sakurai, K., S. Kozasa, and B. Puriyakorn, P. Preechapanya, V. Tanpibal, K. Muangnil, and B. Prachaiyo. 1996. Mineralogical and physico-chemical properties of four Thai soils with special reference to specific surface area (SSA) and zero point of charge (ZPC). Soil Sci. plant Nutr. 42(1):93-103.

Sanchez, P.A., C.A. Palm, C.B. Davey, L.T. Szott, and C.. Rusll. 1985. Tree crops as soil improvers in the humid tropics? In M.G.R. Cannel, and J.E. Jackson (Eds.). Attributes of tree as crop plants. Inst. Of Terrestrial Ecol., Hitungton, England. pp. 327-358.

Schmidt, F.H. and J.H.A. Ferguson. 1951. Rainfall type based on wet and dry period ratios for Indonesia with western New Guinea. Verhandelingen Djawatan Meterologi de Geofisik, Djakarta. 
Soil Survey Staff. 1992. Keys to soil taxonomy. 5th Ed. Soil Management Support Services Technical Monograph No. 19, Blackburg, Virginia. 556 pp.

Received Jan. 25, 2001

Accepted Feb. 5, 2001

Sabaruddin Kadir, 石塚悟史, 櫻井克年, 田中壮太, 久保田しのぶ, 廣田円佳, Satria Jaya Priatna, Juairiah インドネシア，南スマトラにお ける異なる野火履歴をもつアルティソル土袞の性質： I. 物理化学性

インドネシアの熱帯雨林にとって火災は大きな劦威である. しかし, 土壌への野火の影響を定量化した情 報はきわめて限られている. そこで, インドネシアに分布するアルティソル土壌の性質に, 森林火災がも たらす残効について検討した. 本研究では, 異なる野火履歴をもつ種々の生態系下にある土壌の物理化学 性を評価した. 7 つ調査地点は, 火災履歴のない地点 : 保全林(CF), 松林(PF), アカシア植林地(AM), ホームガーデン(HG) と, 被火災地点 : 1995, 1997, 1998年に火災の被害を受けたアカシア植林地（それぞれ, AM-b95, AM-b97，AM-b98)，に大別される. CF, PF, AMでは表層の有機物層が認められたが, その他の地 点には存在しなかった. 土壌形態学的特徵としては, 火災履歴のない地点の土壌は, より暗色のA層を残 していた. 仮比重は地点間で大きな違いはないものの, 火災後の時間経過に伴い減少する傾向にあった. 土壤硬度は被火炎地点の表層で若干大きくなるものの, 植物生育の制限要因となるほどではなかった. 火 災履歴のない地点では被火災地点より, 酸性が強く有機物の蓄積量も多かった. 交換性Ca量はPF, AM-b98, HGで他の地点より高かった. いずれの地点も粘土含量が極めて高いにも関わらず，陽イオン交換容量 (CEC)が低かった. 有効態リン酸含量は低く, 交換性アルミニウムの含量と有意な負の相関が認められた. $\mathrm{Al}, \mathrm{Si}, \mathrm{Fe}$ 酸化物（水酸化物）含量は非晶質のものより結晶質のものが多く, 荷電ゼロ点の值は 4 前後と低 かった. 火災履歴のない地点はある地点より化学的肥沃度がやや高いものの, 調査地のアルティソル土壤 は強風化を受けており, 自然肥沃度そのものが低いことが明らかであった. 